\title{
SPINAL CORD FUNCTION IN PAGET'S DISEASE OF SPINE
}

\author{
By Mr G. RavichandRan, B.Sc., M.B., F.R.C.S.(Ed) \\ National Spinal Injuries Centre, Stoke Mandeville Hospital, \\ Aylesbury, Bucks U.K.
}

\begin{abstract}
The adverse influence of diminished spinal cord blood flow has been well documented. There is increased skeletal blood flow in Paget's disease of bone, with a corresponding reduction in the size of the anterior spinal artery. Use of salmon calcitonin results in rapid reduction in the bone perfusion. The recovery of cord function following calcitonin therapy in patients with paraplegia due to Paget's disease of the vertebral column is likely to be due to enhanced spinal cord perfusion.
\end{abstract}

Key words: Paget's disease of bone; Calcitonin; Cord function.

THERE is considerable controversy regarding the pathogenesis of spinal cord dysfunction in disease or following injury. Paget's disease of bone has been estimated to occur in about 5.4 per cent of the population over the age of 55 years in the United Kingdom (Barker et al., 1977). Sir James Paget (1877), recognised that the disease that bears his name did affect the nervous system, and Wylie (1923) reported the first case of spinal cord compression and paraplegia due to Paget's disease of the vertebrae. Turner (I940) reviewed several cases of paraplegia due to Paget's disease of bone and established cord compression as the major cause. However, Sadar et al. (1972) reported that many of these patients did not have radiologically demonstrable compression. Laminectomy has remained the treatment of choice (Schmidek, I977) in cases of Paget's disease of the vertebral column with associated neurologic changes, on the assumption that most of them have cord compression. The integrity of spinal cord function is now known to depend on $(a)$ its perfusion, $(b)$ absence of cord compression and $(c)$ the mechanical stability of the associated osseous structures. This article attempts to evaluate the relative importance of these factors and to ascertain whether the use of calcitonin improves spinal cord perfusion selectively.

Paget's disease is not a metabolic bone disease. It affects the skeleton in a patchy manner, involving more often lumbosacral spine, pelvis, femora and the skull in descending order of frequency. Cervical spine is affected in only 2 to 4 per cent of patients with Paget's disease of bone (Feldman et al., I969), but 28 per cent of those who have cervical spine involvement develop serious neurologic complications. The diseased bone is soft, vascular and has increased cellular activity. There is purposeless proliferation of osteoclasts which are larger than normal, containing multiple nuclei (Rasmussen \& Bordier, I974). Nuclear inclusion bodies have also been reported (Rebel et al., I977) suggesting a viral aetiology. During the active phase of the disease bone pain is associated with elevated serum alkaline phosphatase and urinary hydroxyproline. There is a concommitant increase in radioactive calcium uptake by the diseased bone. All these suggest that in addition to rapid turn over of cells, the collagen and mineral turnover is also raised in this disease. The disease is generally slowly progressive and rarely self limiting. A small proportion of patients develop sarcomatous changes (Woodhouse, I976). 
The precise mechanism of cord dysfunction in Paget's disease of vertebral column is uncertain. In cases of spinal cord trauma the primary areflexic state is thought to be due to neuronal dysfunction. Korbine (1975) postulated that there is a change in the axonal membrane potential following trauma, at the site of the cord lesion. He argued that this led to temporary defective neurotransmission. Secondary pathological events in the cord following trauma are triggered by the decreased perfusion of the spinal grey matter (Sandler et al., 1976). Yashon (1978) described and confirmed the earlier observations that major and minor spinal cord blood vessels are occluded following trauma, with extravasation in the grey matter. Bingham et al. (1975) reported that spinal white matter perfusion was not hampered up to 4 hours after trauma. These observations led to extensive research on certain biochemical mediators that might be beneficial in preserving cord function (Yashon, 1978; Zivin et al., 1975).

The anticipated effect of prolonged cord compression and further trauma from unstable bony structures was recently verified by Ducker et al. (1978a, b, c). Interestingly these authors established that stability of the spine significantly improved spinal cord recovery in monkeys. Rivlin and Tator (1978) confirmed McDonald's (1975) earlier observations on the effect of prolonged cord compression. They demonstrated a linear relationship between the log of compression time and clinical performance. Thus in rats the clinical effect of cord compression was shown to be inversely related to the duration of compression.

Neuropathological changes of spinal cord in Paget's disease of vertebrae are still unknown. Most authors believe that there is progressive spinal cord compression but cases are on record where no neurologic symptoms were recognised in spite of complete myelographic block in Paget's disease (Siegelman et al., I968). Others have reported neurologic signs in Paget's disease of bone without any demonstrable radiographic block (Petit-Dutaillis et al., 1936). Mathé et al. $(\mathrm{I} 976 a, b)$ could demonstrate signs of anterior spinal artery occlusion without cord compression in cases of Paget's disease of bone. They confirmed the occlusion by selective angiography. Sadar et al. (1972) surmised that this might explain the reversibility of neurologic function in Paget's disease following laminectomy, where no cord compression was seen at operation. In his own review of the published reports of nearly 65 patients who had decompressive laminectomy for Paget's disease of bone, six patients did not improve and six others required further surgical procedures. Clarke and Harrison (I978) reviewed 96 patients with neurologic complications associated with Paget's disease of bone and pointed out that a correlation between the two existed only in patients with cranial nerve lesion and spinal syndromes. They failed to see any correlation between other neurologic states like epilepsy and Paget's disease.

Schumacher et al. (1977) reported two cases of spinal cord compression due to Paget's disease. One of these improved following decompressive laminectomy. Two months after surgery, salmon calcitonin was started and a month after commencement of the drug therapy the patient was able to walk without any help. The second patient reported by these authors had two earlier laminectomies with incomplete recovery. Following the second laminectomy salmon calcitonin therapy was started. The patient improved rapidly and returned to his normal duties as a medical director. Another patient reported elsewhere (Ravichandran, 1979) deteriorated following decompressive surgery and did not improve for 6 weeks. Salmon calcitonin therapy was then commenced. Four weeks after the start of the drug therapy the patient could walk unaided. This patient has maintained clinical remission for over 3 years with complete neurological recovery. 
Nicolle et al. (I977) used porcine calcitonin in a patient with Paget's disease of vertebrae. The extensively diseased vertebrae were not adequately decompressed in this patient. Recovery was gradual and there was recurrence of paraparesis following cessation of drug therapy for I year. The relapse was satisfactorily controlled when calcitonin was resumed. Pépin et al. (1976) and Melick et al. (1976) reported rapid and satisfactory recovery of cord function in patients with Paget's disease of vertebral column. Operative decompression was not done because of the extensive nature of the disease. Calcitonin appears to improve deafness associated with Paget's disease (Moffat et al., I974; Solomon, I977; Shai et al., I97I) even though Grimaldi et al. (1975) failed to verify this observation.

The rapidity of recovery of cord function in patients who did not have decompressive surgery in spite of a myelographic block (Melick et al., 1976; Pépin et al., 1976; Shai et al., I97I) suggests that calcitonin probably has an unknown action on the spinal cord or its perfusion. It is unlikely that administration of calcitonin for a period of 4 weeks or less will effectively relieve cord compression. Further, even when laminectomy has been performed the recovery is seldom rapid. The subsequent administration of calcitonin after decompression resulted in rapid neurologic gains in at least three cases (Schumacher et al., I977; Ravichandran, 1979).

Measurement of spinal cord perfusion generally involves the use of hydrogen clearance technique (Senter et al., 1978). However, such measurements could not be made in humans. Wootton et al. (1976) developed a technique for measurement of skeletal blood flow using ${ }^{18} \mathrm{~F}$. Using this technique they measured the skeletal blood flow in 24 patients with Paget's disease of bone. Fourteen of these were re-examined after short-term or long-term therapy with salmon calcitonin. The skeletal blood flow showed a rapid fall even after one week of calcitonin therapy (Wootton et al., I978).

It is well known that the intercostal arteries supply both the Pagetic vertebrae and the segmental artery to the spinal cord. During the active phase of the disease the skeletal blood flow is increased by at least a factor of three (Wootton et al., I976) with a relative reduction of cord blood flow. Mathé and Fève (1976) showed attenuation of the anterior spinal artery in cases of Paget's disease of the vertebra. They also demonstrated a definite delay in the filling of the anterior spinal artery during selective angiography. The reduction in skeletal blood flow following calcitonin therapy (Wootton et al., I978) is likely to improve the segmental spinal cord perfusion. This might explain the rapidity of recovery of spinal cord function following calcitonin therapy. Laminectomy may prove unnecessary in Paget's disease of bone where compression of the cord is uncertain since clinical improvement may be obtained from calcitonin therapy alone. Furthermore, laminectomy has been shown to reduce spinal cord blood flow in experimental animals (Anderson et al., 1978). This might explain the deterioration of cord function following laminectomy in certain instances (Ravichandran, 1979). The frugally perfused spinal cord segment at the level of the diseased vertebra may suffer further insult during laminectomy leading to deterioration of cord function.

It should be remembered however that chronic compression due to narrowed spinal canal in Paget's disease cannot be adequately relieved by calcitonin alone. Decompressive surgery has been shown to be beneficial in many instances (Turner, 1940). It is not uncommon to see fractures in Pagetic bones and these may lead to further cord compression. It may be necessary in theseinstances to provide adequate immobilisation to avoid further damage to cord perfusion (Ducker et al., 1978c). 


\section{Conclusion}

Paget's disease of the vertebra increases skeletal blood flow resulting in reduction in spinal cord perfusion. Use of salmon calcitonin decreases the skeletal blood flow rapidly. The associated rapid neurologic recovery is most likely due to improved segmental spinal cord circulation. Laminectomy would lead to further fall in spinal cord blood flow and should be avoided unless there are definite signs of cord compression.

\section{RÉSUMÉ}

La maladie de Paget des vertebres augmente la circulation sanguine osseuse résultant en la reduction de la perfusion de la corde épinierè. Sous l'effet de la calcitonnine. La circulation sanguine osseuse diminue rapidement. Le rétablissement des fonctions neurologique est probablement dû à l'amelioration de la circulation sanguine segmentale de la corde épinière. Il se peut que la laminectomie diminue encore plus la circulation épinière; pour cette raison elle doit ètre évitée, à moins qu'il y ait des signes definitifs de compression sur la cord épinière.

\section{ZUSAMMENFASSUNG}

Paget's Krankheits-Befall der Wirbelerhöht die skelettale Blutversorgung und vermindert dadurch die spinale Durchblutung. Salmon calcitonin vermindert die skelettdurchblutung. Die darauf folgende neurologische Besserung beruht wahrscheinlich auf der verbesserten segmentalen Blutversorgung. Eine Laminectomie würde zu einer weiteren schlecteren spinale Durchblutung führen und sollte vermieden werden, falls nicht eindeutige Zeichen auf eine Rückenmarkskompression hinweisen.

Acknowledgement. The author wishes to thank Dr Francis Jones and Dr J. R. Silver for their helpful criticisms and advice.

\section{REFERENCES}

Andersen, D. K., Nicolosi, G. R., Means, E. D. \& Hartley, L. E. (i978). Effects of laminectomy on spinal cord blood flow. Fournal of Neurosurgery, 48, 232-238.

Barker, D. J. P., Clough, W. L., Guyer, P. B. \& Gardner, M. J. (I977). Paget's disease of bone in I4 British towns. British Medical fournal, I, I I8I-I I83.

Bingham, W. G., Goldman, H., Friedman, S. J., Murphy, S., Yashon, D. \& Hunt, W. E. (1975). Blood flow in normal and injured monkey spinal cord. Fournal of Neurosurgery, 43, I62-I7I.

Clarke, C. R. \& Harrison, M. J. G. (1978). Neurological manifestations of Paget's disease. Fournal of Neurological Sciences, 38, I7I-I78.

Ducker, T. B., Salcman, M., Perot, P. L. \& Ballantine, D. (1978). Experimental spinal cord trauma. I. Correlation of blood flow, tissue oxygen and neurologic status in the dog. Surgical Neurology, 10, 60-63.

Ducker, T. B., Salcman, M., Lucas, J. T., Garrison, W. B. \& Perot, P. L. (1978). Experimental spinal cord trauma. II. Blood flow, tissue oxygen, evoked potentials in both paretic and plegic monkeys. Surgical Neurology, 10, 64-70.

Ducker, T. B., SAlcman, M. \& Daniell, H. B. (1978). Experimental spinal cord trauma. III. Therapeutic effect of immobilisation and pharmacologic agents. Surgical Neurology, I0, 7 I-76.

Feldman, F. \& Seaman, W. B. (1969). The Neurological Complications of Paget's disease in the Cervical Spine. American fournal of Roentgenology, 105, 375-382.

Grimaldi, P. M. G. B., Mohamedally, S. M. \& Woodhouse, N. J. Y. (I975). Deafness in Paget's disease: effect of salmon calcitonin treatment. British Medical fournal, $\mathbf{7 2 6 .}$

Korbine, A. I. (1975). The neuronal theory of experimental traumatic spinal cord dysfunction. Surgical Neurology, 3, 26I-264.

MCDONALD, W. I. (I975). Mechanism of functional loss and recovery in spinal cord damage. In 'Outcome of severe damage to nervous system', Ciba Foundation Symposium, Vol. 34, pp. 23-33. 
MathÉ, J. F., \& FÈve, J. R. (I976). Trois cas d'ischémie de la molle par compression des artères radiculomedullaires-avec angiographie sélective. Le fournal des Agreges, 9, 399-407.

Mathé, J. F. \& Pannier, S. (I976). Myélopathie au cours d'une maladie de Paget. Incidence du facteur vasculaire, confirmée par angiographie médullaire. Annales de Médecine Physique, 19, I78-I82.

Mathé, J. F., Delubel, R., Resche, F., Cler, J. M. \& Fève, J. R. (1976). Syndromes médullaires au cours de la maladie de Paget. La Nouvelle Presse Médicale, 39, 26I9-262I.

Melick, R. A., Ebling, P. \& HJORTH, R. J. (1976). Improvement in paraplegia in vertebral Paget's disease treated with calcitonin. British Medical fournal, 627-628.

Moffat, W. H., Morrow, J. D. \& Simpson, N. (I974). Effects of calcitonin therapy in deafness associated with Paget's disease of bone. British Medical fournal, 203.

Nicolle, M. H., Grondard, E., François, N. \& Maury, M. (I977). À propos d'une Paraplégie Pagétique traitée avec succès par la calcitonine avec un récul de plus de 4 ans. Thérapie, 32, 603-609.

PAGET, Sir J. (I877). On a form of chronic inflammation of bone (osteitis deformans). Transactions of Medical Chirurgical Society, 6o, 37-64.

Pépin, B., Hubault, A., Goldstein, B., Bourdarias, H. \& Lidy, C. (1976). Évolution régressive sous l'effet de la calcitonine d'une compression médullaire Pagétique. Annales de Médicine Interne (Paris), 127, 243-246.

Rassmussen, H. \& Bordier, P. (1974). The Physiological and Cellular Basis of Metabolic Bone Disease, p. 297, Williams and Wilkins, Baltimore.

RAVICHANDRAN, G. (I979). Neurologic recovery of paraplegia following use of calcitonin in a patient with Paget's disease of spine. Spine, 4, 37-40.

Rebel, A., Malkani, K., Basle, M. \& Bregeon, Ch. (I977). Is Paget's bone disease a viral infection? Calcified Tissue Research, 22, 283.

Rivlin, A. S. \& TATOR, C. H. (1978). Effect of duration of acute spinal cord compression in a new acute cord injury model in rats. Surgical Neurology, 10, 39-43.

SAdAR, E. S., Walton, R. J. \& Gossman, H. H. (1972). Neurological dysfunction in Paget's disease of the vertebral column. Fournal of Neurosurgery, 37, 66 I-665.

SANDlER, A. N. \& TATOR, C. H. (1976). Review of the effect of spinal cord trauma on the vessels and blood flow in the spinal cord. Fournal of Neurosurgery, 45, 638-646.

SCHIMEDEK, H. H. (1977). Neurologic and neurosurgical sequelae of Paget's disease of bone. Clinical Orthopaedics and Related Research, 127, 70-77.

Schumacher, M., LeVY, A., BECK, V. \& RAMAGEN, W. (I977). Paget's disease with spinal cord compression. European Neurology, I5, I I6-I 20.

Senter, H. J., Burgess, D. H. \& MELTZLER, J. (I978). An improved technique for measurement of spinal cord blood flow. Brain Research, 149, I97-203.

Shai, F., BakeR, R. K., \& Wallach, S. (I97I). The Clinical and metabolic effects of porcine calcitonin on Paget's disease of bone. Fournal of Clinical Investigation, 50, I927-I940.

Siggelman, S. S., Levine, S. A. \& Walpin, L. (I968). Paget's disease with spinal cord compression. Clinical Radiology, 19, 42 I-425.

Turner, A. J. W. (I940). The spinal complications of Paget's disease. Brain, 63, 32 I-349.

Woodhouse, N. J. Y. (I976). Paget's disease-a review and indication for treatment with calcitonin. In 'Bone Disease and Calcitonin', Armour Pharmaceutical Company, England.

Wootton, R., ReEve, J. \& Veall, N. (1976). The clinical measurement of skeletal blood flow. Clinical Science and Molecular Medicine, 50, 26I-268.

Wootton, R., ReEve, J., Spellacy, E. \& Tellez-Yudilevich, M. (1978). Skeletal blood flow in Paget's disease of bone and its response to calcitonin therapy. Clinical Science and Molecular Medicine, 54, 69-74.

WyLIE, W. G. (I923). The occurrence in osteitis deformans of lesions of the central nervous system, with a report of four cases. Brain, 46, 336-35I.

Yashon, D. (1978). Pathogenesis of spinal cord injury. Orthopaedic Clinics of North America, 9, 247-26I.

Zivin, J. A., Reid, J. L., SAavedra, J. M. \& Kopin, I. J. (I975). Quantitative localisation of biogenic amines in the spinal cord. Brain Research, 99, 29I-30I. 